Sains Malaysiana 50(1)(2021): 227-238

http://dx.doi.org/10.17576/jsm-2021-5001-22

\title{
Investigation on Structural Behaviour of Bamboo Reinforced Concrete Slabs under Concentrated Load
}

(Kajian ke atas Sifat Struktur Slab Konkrit diperkuat Buluh di bawah Beban Tertumpu)

Yanuar Haryanto, Nanang Gunawan Wariyatno, Hsuan-Teh Hu*, Ay Lie Han \& Banu Ardi Hidayat

\section{ABSTRACT}

Reinforced concrete is perhaps the most widely used building material in the world. However, the materials used for reinforcement of concrete i.e. steel is quite expensive and scarcely available in the developing world. As a result, bamboo is considered to be a cheaper replacement with high tensile strength. This research investigated the structural behaviour of bamboo-reinforced concrete slabs used for footplate foundation subjected to concentrated load. For this purpose, four different reinforced concrete slab panels were developed and analyzed. The influence of replacing steel with bamboo for the reinforcement of concrete slabs on their structural behaviour was assessed by determining the load-deflection characteristics, the ultimate load, the stiffness, the ductility, the cracking pattern, and the energy absorption capacity. The results showed that in comparison to steel reinforced concrete slabs, the strength of $82 \%$ can be acquired by the bamboo reinforced slabs. Furthermore, ductility demonstrated by the two types of specimens was almost equivalent i.e. up to 93\%. Those indicated that the structural behaviour demonstrated by bamboo reinforced slabs is quite comparable to that of steel reinforced concrete slabs. Therefore, bamboo can prove to be a promising substitute for steel in concrete reinforcement. Future studies may further examine this opportunity.

Keywords: Bamboo reinforced concrete; concentrated load; slab; structural behaviour

\section{ABSTRAK}

Konkrit diperkuat ialah bahan pembinaan yang digunakan secara meluas di seluruh dunia. Namun, bahan yang digunakan untuk memperkuatkan konkrit seperti keluli agak mahal dan sukar didapati di negara sedang membangun. Oleh itu, buluh telah dianggap sebagai bahan pengganti yang lebih murah dengan kekuatan regangan yang tinggi. Penyelidikan ini mengkaji sifat struktur konkrit diperkuat oleh buluh yang digunakan untuk tapak plat kaki dalam beban tertumpu. Bagi tujuan ini, empat panel slab konkrit yang diperkuat telah dibangunkan untuk dikaji sifat strukturnya. Kesan penggantian keluli menggunakan buluh sebagai bahan diperkuat kepada konkrit ke atas sifat struktur telah dikaji untuk menentukan ciri beban-pesongan, beban muktamad, kekakuan, kemuluran, corak retakan dan muatan penyerapan tenaga. Keputusan menunjukkan bahawa berbanding dengan konkrit diperkuat keluli, 82\% kekuatan telah tercapai dengan penggunaan buluh. Tambahan pula, kemuluran yang ditunjukkan oleh dua jenis spesimen hampir setara iaitu hingga 93\%. Ini menunjukkan bahawa sifat struktur yang ditunjukkan oleh slab diperkuat buluh agak setanding dengan slab konkrit diperkuat keluli. Oleh itu, buluh berpotensi menjadi pengganti keluli dalam peneguhan konkrit. Kajian pada masa depan boleh mengkaji lebih lanjut peluang ini.

Kata kunci: Beban tertumpu; konkrit diperkuat buluh; sifat struktur; slab

\section{INTRODUCTION}

Perhaps the most widely used building material all across the globe is the reinforced concrete (RC). It is available on an industrial scale and can be found almost everywhere. Due to the impressive durability of concrete structures, it has been used in place of inexpensive building materials such as brick and mud houses. The materials and methods required for making concrete are quite inexpensive and economical. However, steel is generally used to reinforce concrete. Some disadvantages are its non-renewable nature (Agarwal et al. 2014), high cost (Karthik et al. 2017), and limited availability in certain parts of the world (FergussonCalwell 2015).

Scientists are in search of inexpensive materials and manufacturing processes that use less energy (AnguloIbáñez 2017). In this context, materials like plants, industrial waste, and vegetal fibers including soil, have attracted interest since they are renewable, recyclable, 
inexpensive, and sustainable as well. However, developing countries around the world are training their students with knowledge and materials adopted from developed parts of the world. As a result, they do not have sufficient formal education and research programs regarding traditional materials and procedures.

Some natural materials available locally can be used in concrete to improve its durability and environmentally friendly nature. Bamboo is one of those substances. It belongs to the Grass family (Anandamurthy et al. 2017) and only one ton of carbon dioxide is consumed by its growth. This is much less than the amount of carbon dioxide released during the production of cement and steel (Xiao et al. 2013). Bamboo can be a promising sustainable replacement for traditional steel reinforcement, not only because of its fastest growth but also due to its renewability and environmentally friendly nature. Currently, more than 1,200 species of bamboo have been discovered worldwide (Sharma et al. 2015b). Environmental factors like location, water, climate, and type of soil determine the availability of different species of bamboo (Mali \& Datta 2018). Intriguingly, the regions near the developing states of the world are rich in bamboo and so is the case of small villages of these states.

The possibility of using bamboo as reinforcements in structural concrete has been investigated by several researchers (Archila et al. 2018; Ghavami 1995, 2005; Rahman et al. 2011). One of such study was performed by Terai and Minami (2011) who analyzed the possibility of using bamboo to reinforce concrete columns and beams. As per this research, the existing formula of $\mathrm{RC}$ beam can be used to evaluate the fracture behaviour demonstrated by bamboo reinforced concrete (BRC) beam. Furthermore, the study showed that the ductility of BRC columns depends on the concrete strength. Agarwal et al. (2014) carried out a comparison of various adhesives (Anti Corr RC, Araldite, Sikadur 32 gel, and Tapecrete $\mathrm{P}-151)$ and reported that the highest bonding strength at the interface of a bamboo concrete composite is achieved with Sikadur 32 gel. The ductile nature is demonstrated by the BRC column treated with Sikadur 32 gel, and it offers adequate warning before failure. In addition, it was found that the utilization of treated bamboo (only $1.49 \%$ by area) for reinforcement allowed a $29.41 \%$ increment in the load-carrying capacity of the beam.

It has been reported by Karthik et al. (2017) that under flexural loading, performance demonstrated by BRC comprising of substitute substances such as manufactured sand (m-sand), Ground Granulated Blast Furnace Slag (GGBS), and fly ash was considerably low compared to BRC which contains traditionally used materials. This is due to the poor bonding of bamboo and concrete containing substitute substances.
Moreover, increment in size of bamboo reinforcement and in number of days taken for curing have led to an improvement in the flexural performance of the BRC beam (Dey \& Chetia 2018). In comparison to unreinforced masonry, the utilization of bamboo reinforcement in concrete block shear walls results in enhanced ductility and shear capacity (Moroz et al. 2014). A replacement component of a sustainable infrastructure was developed by Puri et al. (2017). Prefabricated bamboo reinforced walls have proven to be advantageous for cheap housing. Compared to partition bricks, they offer good durability, a $40 \%$ lower cost, and a 56\% lower weight. Significant benefits of using these walls have been observed instead of using conventional bricks.

The tensile strength and axial compression of bamboo concrete composites are very high. Therefore, they are ideal for frames and other structures that dominate with axial force (Dewi \& Nuralinah 2017). Such a composite can be used as a replacement for the wooden roof frame and should be made either in precast or insitu cast concrete. The performance of precast segmental bamboo reinforced concrete beams has been evaluated by Haryanto et al. (2019a) after exposing them to flexural loads. A flexural failure mechanism was indicated by the pattern of crack observed in the control beam. On the contrary, a shear failure mechanism was indicated in the precast segmental bamboo reinforced concrete beams. In comparison with the precast segmental bamboo reinforced concrete beams containing four bolted connections, the same containing six bolted connections demonstrated better performance. Several types of research have been attracted to the improvement of RC structures in recent years and this has turned bamboo into a strengthening material (Haryanto et al. 2017; Hidayat et al. 2019; Nahar \& Rahman 2015; Sen \& Reddy 2011; Xu et al. 2019).

Concrete slabs are generally solid, low-height structures compared to other dimensions (Wariyatno et al. 2017). Since the first use of the modern RC slab, almost all buildings use this material as the plate elements. Several researchers have investigated the utilization of bamboo strip as the main material in reinforcing slab panels (Bhonde et al. 2014; Chithambaram \& Kumar 2017; Kankam \& Odum-Ewuakye 2006, 2001; Wibowo et al. 2017). Mali and Datta (2018) have examined the bamboo reinforced concrete slab panels and found that these BRC structural components can be used in low-cost housing, especially as a component of roofing in the case of limited gravity loading. In comparison to traditionally used RC slabs, they are environment friendly and inexpensive. The strength behaviour of BRC slabs has been studied by Ismail et al. (2018). The bending response of the slab structure was reported to improve with an increasing degree of the main reinforcement. Bambusa bamboo has 
been utilized as main reinforcement by Maruthupandian et al. (2016) in slab specimens and was discovered that it can be used in place of steel with minimal loading for structural applications. According to Zhu et al. (2015), the steel reinforced concrete (SRC) slab is slightly better than BRC slab. However, at a load of $40 \mathrm{kN}$, the same deflection is demonstrated. Therefore, bamboo can be used as a structural material in minimal loading applications like book slabs and kitchen slabs.

To date, in the available literature, there are little or no sufficient data on BRC slab subjected to concentrated load. Therefore, in this study, bamboo was used as the reinforcing material in the slab specimen for the utilization of footplate foundations, and their structural behaviour was investigated. For this purpose, four different reinforced concrete slab panels were fabricated and evaluated. The Universal Testing Machine (UTM) has been used for conducting experimental tests on the specimens using one-point loading configuration. The properties observed in the specimens include ultimate load and load-deflection characteristics, failure mode, crack pattern, stiffness, and ductility. Moreover, energy absorption capacity was also examined.

\section{MATERIALs AND Methods}

Bamboo, steel, potable water, coarse aggregate, river sand, and cement has been used in this research. Ordinary Portland cement was used in particular, and it shows compliance with SNI 15-2049-2004 (BSN 2004). After the aggregates were dried, they were sieved using a $2.36 \mathrm{~mm}$ sieve and treated in accordance with SNI 031968-1990 (BSN 1990). The physical characteristics of the aggregates are shown in Table 1. The top part of string bamboo (Gigantochloa apus) locally available in Indonesia was used. While selecting bamboo culm, it is ensured that the overall geometry is sufficiently straight and free from fungus or damage, to allow the final samples to reflect well-distributed fibers. This exercise helped the selection of good samples with good physical and mechanical properties (Mali \& Datta 2018; Sharma et al. 2015a).

Bamboo strips demonstrated an average tensile strength of $138 \mathrm{MPa}$. During the initial treatment, they were soaked at $27{ }^{\circ} \mathrm{C}$ for two days, and they were then sun-dried for about thirty days to achieve a reasonable level of dryness. It is important to take some precautions before using bamboo to avoid any fungal growth or pores, signs of decay and blemishes or deterioration. Bamboo strips were carefully greased before casting slab specimens. It improves the bonding to the concrete matrix and prevents the absorption of moisture.

TABLE 1. Physical properties of aggregates

\begin{tabular}{lccc}
\hline \multicolumn{1}{c}{ Aggregates } & Specific gravity & Water absorption (\%) & Fineness modulus \\
\hline Fine aggregate & 2.45 & 4.42 & 4.25 \\
Coarse aggregate & 2.69 & 2.04 & 7.24 \\
\hline
\end{tabular}

\section{DESIGN AND SPECIMEN PREPARATIONS}

Since concrete is a common part in this research, a grade of it (M18) was used. The SNI 1974: 2011 (BSN 2011) guidelines were adopted to perform the mix design and the testing of the concrete specimens. Table 2 indicates the final mix proportion. For the mixed design, coarse aggregates of sizes $10 \mathrm{~mm}$ and $20 \mathrm{~mm}$ were used in combination. These were mixed in a ratio of $30: 70$ so that the concrete mass having aggregate size of $10 \mathrm{~mm}$ can easily accommodate in semi-circular groove. In this way, bamboo concrete interlocking is established.

TABLE 2. Mix design of concrete

\begin{tabular}{lcccc}
\hline & \multicolumn{2}{c}{ Ingredients $\left(\mathrm{kg} / \mathrm{m}^{3}\right)$} & \multicolumn{2}{c}{ Compression (MPa) } \\
\hline Cement & Fine aggregate & Coarse aggregate & Obtained strength & Design strength \\
\hline 350 & 563 & 1253 & 19.73 & 18 \\
\hline
\end{tabular}


Once casting and curing (28 days) of concrete specimens has been completed, the compressive strength of specimens was determined as mentioned in Table 2 . The slab specimens subjected to a concentrated load configuration test were categorized into four groups. One group comprised of control which was steel reinforced concrete slab with $8 \mathrm{~mm}$ diameter steel bars (SRC8). The rest of the three groups contained BRC slab panels. The specimens were distinguished based on the type of bamboo reinforcement used. In particular, one group comprised of bamboo reinforced concrete slab with bamboo of $8 \times 8 \mathrm{~mm}$ strip (BRC8), another group comprised of bamboo reinforced concrete slab with bamboo of $10 \times 10 \mathrm{~mm}$ strip (BRC10) and third group comprised of bamboo reinforced concrete slab with bamboo of $12 \times 12 \mathrm{~mm}$ strip (BRC12).

\section{EXPERIMENTAL INVESTIGATIONS}

In order to carry out experiments, the square was casted with SRC8, BRC8, BRC10, and BRC12 slab specimens. The reinforcement cage designed for the control and BRC specimens is illustrated in Figure 1. This cage was then positioned uniformly in the mold with a cover of 20 $\mathrm{mm}$ from the bottom and on all four sides. In the case of the SRC8 slab, $8 \mathrm{~mm}$ diameter steel bars were used with a yield strength of $230 \mathrm{MPa}$ positioned at $150 \mathrm{~mm} \mathrm{c} / \mathrm{c}$. The casting of all four slabs was conducted in the laboratory. Once casting was performed, the slab specimens were left for setting at room temperature $\left(28{ }^{\circ} \mathrm{C}\right)$ and $50 \%$ humidity within the laboratory. After $24 \mathrm{~h}$, the specimens were demolded and placed in curing tank for 28 days at normal temperature.

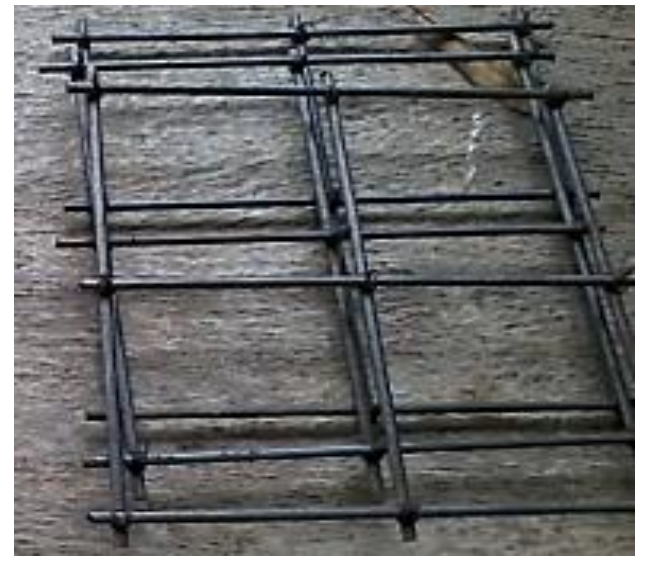

a) SRC specimens

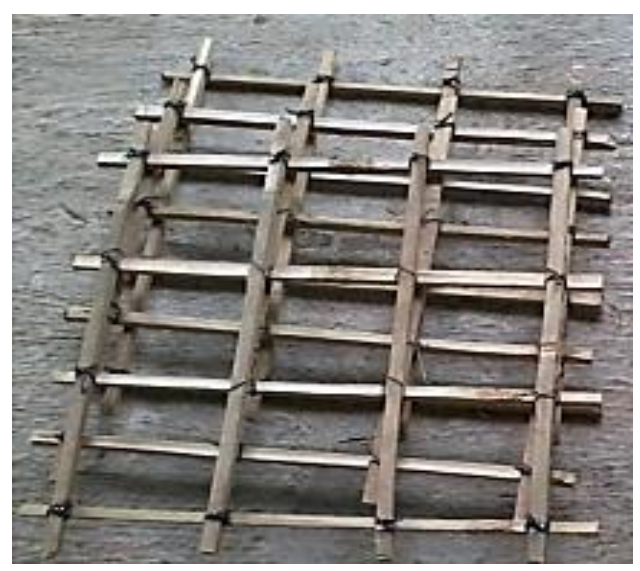

b) BRC specimens

FIGURE 1. Arrangement of reinforcement 
Figure 2 indicates the detailed dimensions of the slab specimens. Each of them had a size of $600 \times 60 \times 70$ $\mathrm{mm}$. In the case of BRC8 slab specimen, the cross-section of bamboo strip was $8 \times 8 \mathrm{~mm}$, and the spacing was 75 $\mathrm{mm} \mathrm{c/c}$. For BRC10 slab specimen, the cross-section of bamboo strip was $10 \times 10 \mathrm{~mm}$, and $100 \mathrm{~mm} \mathrm{c} / \mathrm{c}$ was the spacing. Finally, in the case of BRC12 slab specimen, the cross-section of bamboo strip used was $12 \times 12 \mathrm{~mm}$ and $150 \mathrm{~mm} \mathrm{c} / \mathrm{c}$ were the spacing of bamboo reinforcement. The total length of each bamboo used was $360 \mathrm{~mm}$ in every principal direction of the slab specimens.

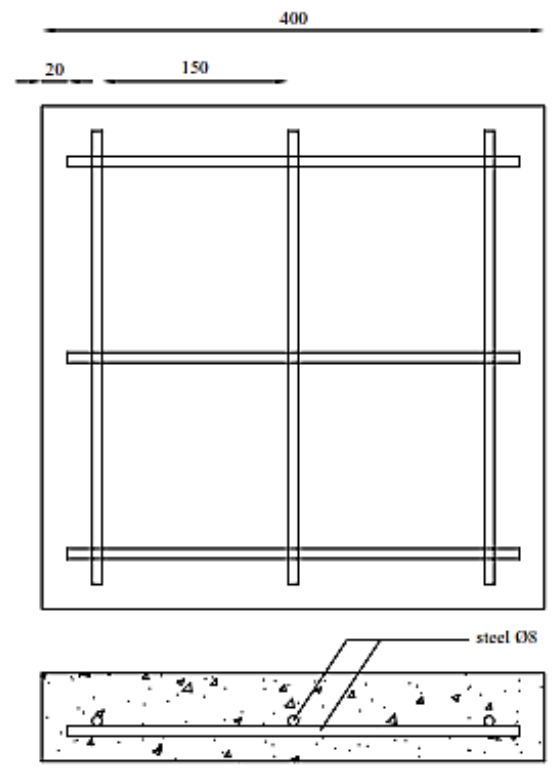

a) SRC8 slab specimen
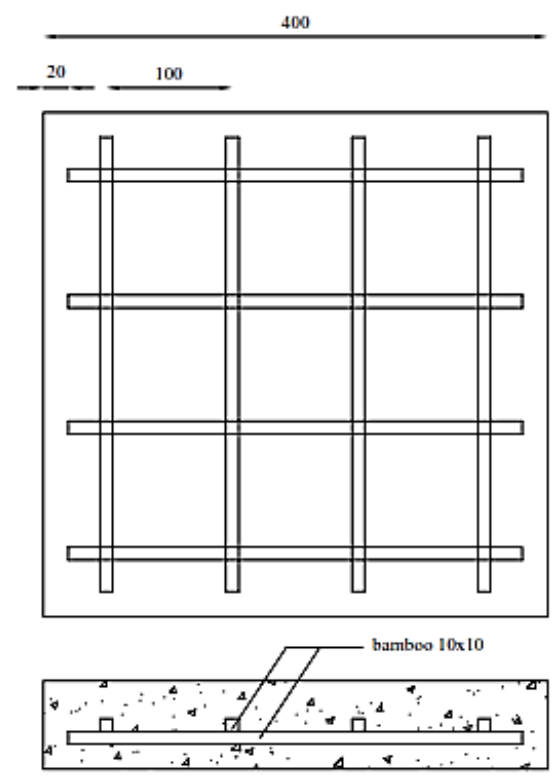

c) BRC10 slab specimen

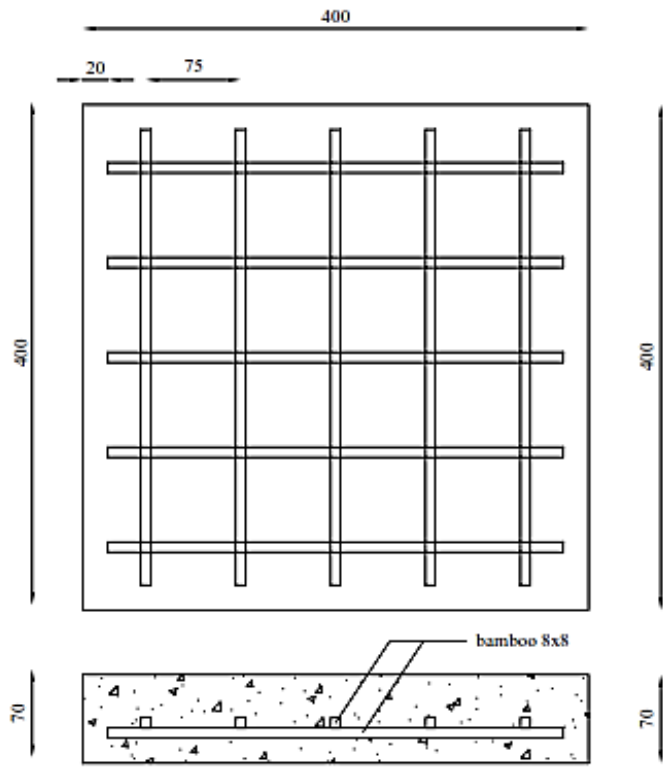

b) BRC8 slab specimen

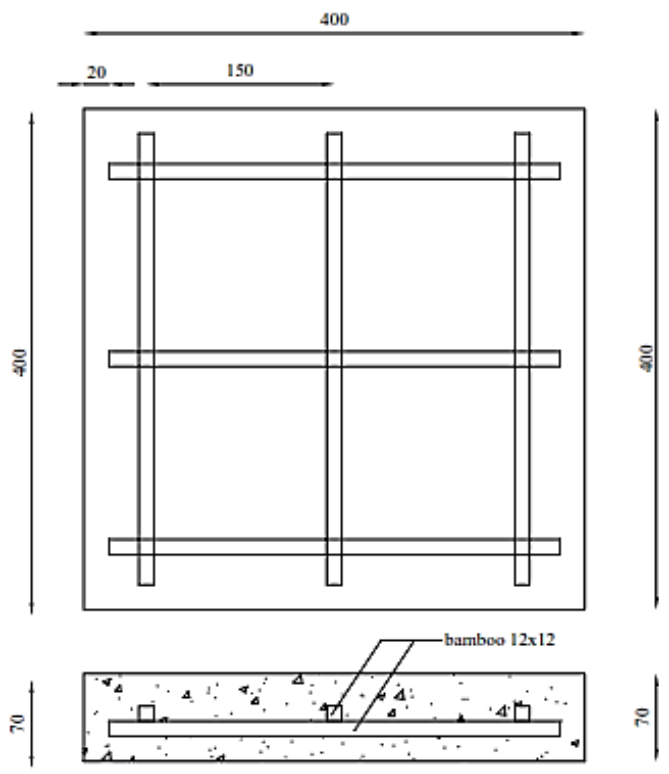

d) BRC12 slab specimen

FIGURE 2. The details of slab specimens 


\section{TESTING METHODS}

A Universal Testing Machine (UTM) with a capacity of $200 \mathrm{kN}$ was used for the experiments. As shown in Figure 3, slab specimens were placed on a square shaped supporting frame composed of hard steel having L-section acts being fixed at the four sides. The specimen was positioned inside the set up made for a concentrated loading configuration test (Figure 4). The fixed bottom support, central cross-section, loading surface, and loading head were designed to lie in a single vertical plane. This was followed by a gradual application of load at the interval of $20 \mathrm{~N} / \mathrm{s}$. A calibrated electronic control system was used to record observations of load and deformation. This system was connected to a host PC. The load and deflection at point of ultimate failure were documented. Crack patterns were also observed visually and recorded.

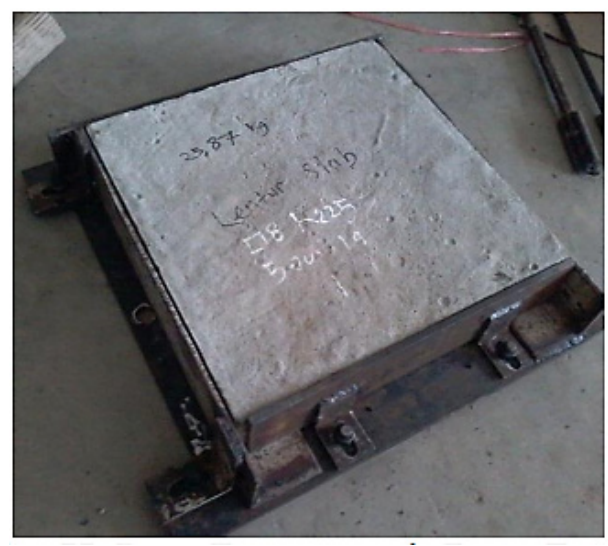

FIGURE 3. Slab specimen with fixed at four edges

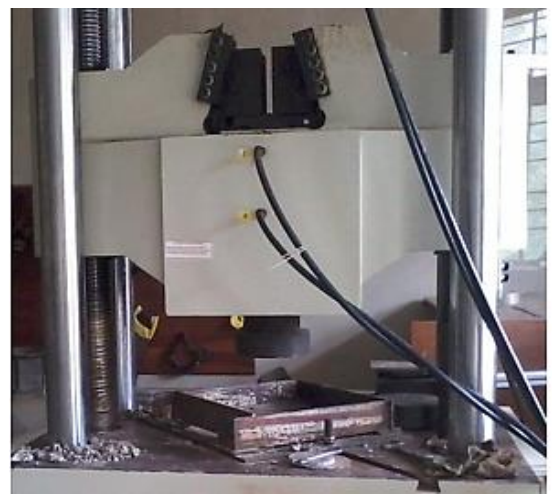

a) Universal Testing Machine (UTM) for slab test

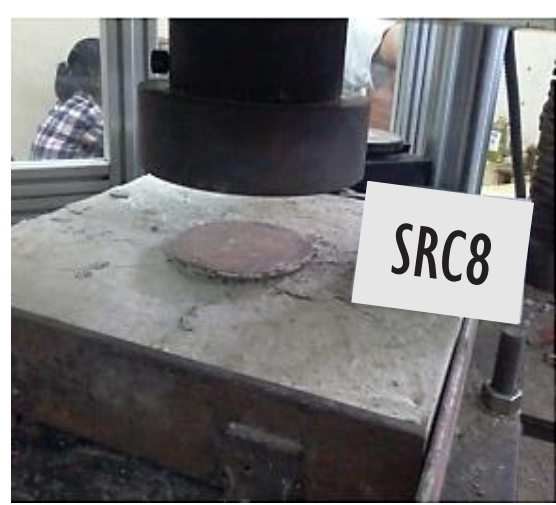

b) Concentrated loading configuration test

FIGURE 4. Test setup 


\section{RESULTS AND DISCUSSION}

The results recorded for the experiment are detailed in the following sections. In particular, the load versus mid-span deflection response curve, failure modes, load-carrying capacity, ductility, stiffness, and energy absorption capacity were determined.

\section{LOAD-DEFLECTION CHARACTERISTICS AND FAILURE MODES}

The deflection at which the load, after achieving the ultimate value, has dropped to $80 \%$ of the ultimate load is considered to be the failure deflection. While the deflection at the theoretical yield point of an equivalent elasto-plastic system is considered as the yield deflection. Equivalent elastic stiffness of this elasto-plastic system was considered as secant stiffness at $75 \%$ of the ultimate load prior to the point where the ultimate load was reached. Yield strength was considered to be the ultimate load (Haryanto et al. 2019b, 2018, 2017, 2012).

The characteristic curves plotted as a function of the load for the central deflection are shown in Figure 5. Also, Table 3 shows the results of the tests, which provide the values of ultimate load $\left(P_{u}\right)$, central deflection at the theoretical yielding of the flexural reinforcement $\left(\delta_{y}\right)$, at ultimate load $\left(\delta_{u}\right)$, at failure load $\left(\delta_{f}\right)$, and failure modes of different slab specimens tested during the experiment. The researchers noticed that the deflection increased with the increase in the load. After the theoretical yield points, the deflection of the slabs was suddenly changed. In comparison to the steel reinforced slabs, the bamboo reinforced slabs demonstrated a greater degree of deflection at ultimate load $\left(\delta_{u}\right)$. It shows that the flexibility coefficient of the materials used for reinforcement influences the deformation properties of the slabs (Audu \& Raheem 2017).

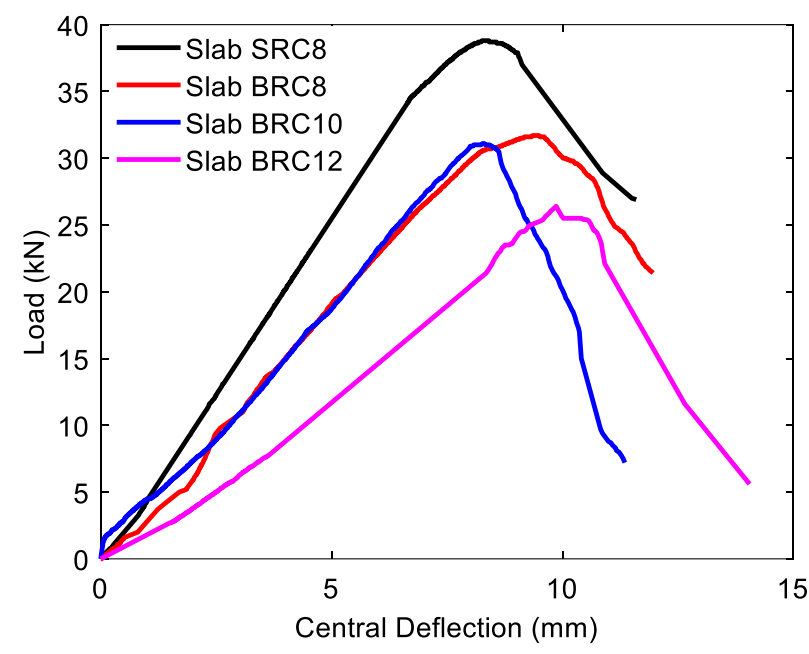

FIGURE 5. Load-deflection characteristics of tested slabs

TABLE 3. Summary of ultimate loads and failure modes

\begin{tabular}{lcccccc}
\hline \multicolumn{1}{c}{ Specimen } & $\mathrm{P}_{\mathrm{u}}(\mathrm{kN})$ & Ratio & $\delta_{\mathrm{y}}(\mathrm{mm})$ & $\delta_{\mathrm{u}}(\mathrm{mm})$ & $\delta_{\mathrm{f}}(\mathrm{mm})$ & Failure Modes \\
\hline SRC8 & 38.80 & 1.00 & 7.39 & 8.40 & 10.42 & Shear failure \\
BCR8 & 31.70 & 0.82 & 8.40 & 9.49 & 11.05 & Shear failure \\
BCR10 & 31.10 & 0.80 & 8.31 & 8.64 & 9.32 & Shear failure \\
BCR12 & 26.40 & 0.68 & 10.16 & 10.16 & 11.10 & Shear failure \\
\hline
\end{tabular}


As shown in Table 3, the traditionally used RC slab containing $8 \mathrm{~mm}$ diameter steel bars (SRC8) in the two principal directions was capable of supporting an ultimate load of $38.80 \mathrm{kN}$ at $8.4 \mathrm{~mm}$ central deflection. Linear elastic behaviour has been demonstrated by the SCR8 slab up to the point where load almost acquired a constant value when the theoretically yielded flexural reinforcement is at $0.75 P_{u}$ or $29.10 \mathrm{kN}$ (Figure 5). It is evident from the pattern of the cracks at tension face (bottom side) of the slab (Figure 6) that the failure of SCR8 slab occurred due to diagonal tension cracks. This is in agreement with the findings of Mali and Datta (2018) research.
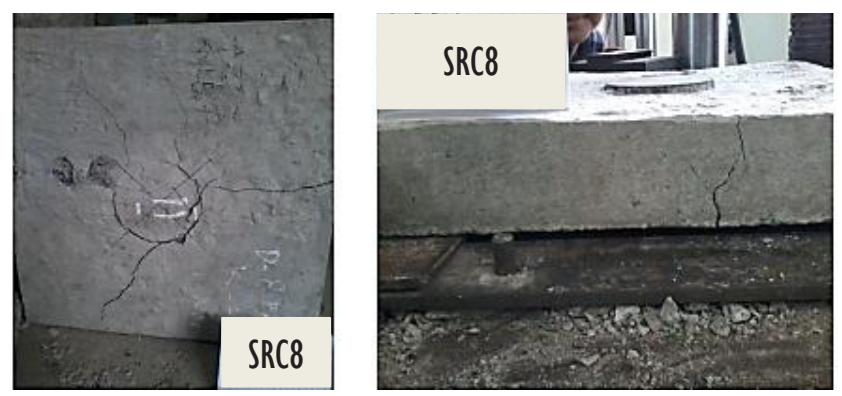

FIGURE 6. Crack pattern in SRC8 slab

The BRC8 specimen containing $8 \mathrm{~mm} \times 8 \mathrm{~mm}$ bamboo strips in the two principal directions underwent the failure mode same as that of the control SRC8 specimen. This can be stated by viewing the pattern of cracking (Figure 7) as it is almost same for both. The BRC8 specimen achieved $31.7 \mathrm{kN}$ ultimate load with 9.49 mm central deflection after demonstrating linear elastic behaviour up to a point where load almost approached the constant value at acquisition of the theoretically yielded flexural reinforcement at $0.75 P_{u}$ or $23.78 \mathrm{kN}$. In comparison to the control specimens, $82 \%$ strength has been achieved by the BRC 8 specimen.
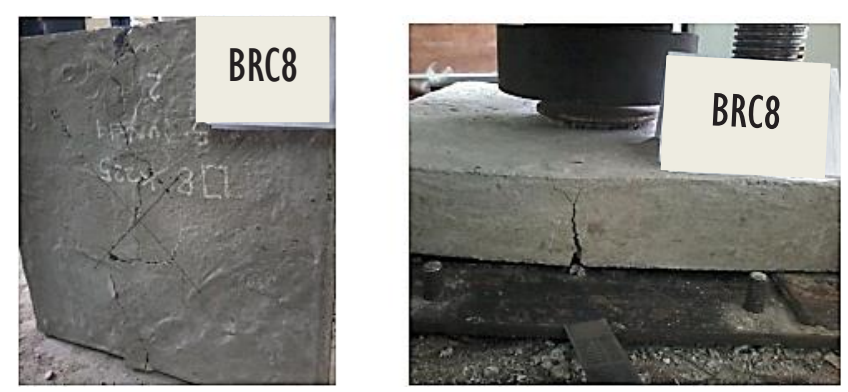

FIGURE 7. Crack pattern in BRC8 slab

The crack pattern (Figure 8) was also examined to assess the failure mode of the BRC10. After originating from the tension side at the periphery of the circular loading plunger, the cracks of BRC10 slab propagated diagonally towards every corner showing failure of shear mode (Mali \& Datta 2018). As indicated by Figure 5, linear elastic behaviour has been demonstrated by the BRC10 specimens up to a point when load almost approached the constant value at acquisition of theoretically yielded flexural reinforcement at $0.75 P_{u}$ or $23.33 \mathrm{kN}$. The ultimate load in this case was $31.10 \mathrm{kN}$ which is $80 \%$ of the ultimate load for control specimen and the central deflection was $8.64 \mathrm{~mm}$. 

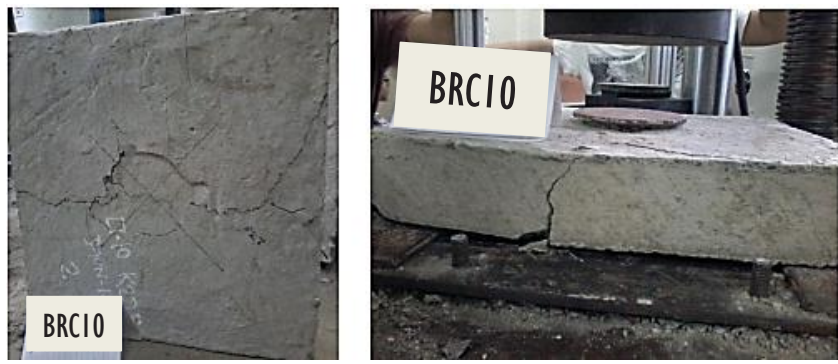

FIGURE 8. Crack pattern in BRC10 slab

Before the failure, the linear elastic behaviour has also been demonstrated by the BRC12 specimen up to a point where load almost approached a constant value at the acquisition of theoretically yielded flexural reinforcement at $0.75 P_{u}$ or $19.5 \mathrm{kN}$ as shown in Figure 5. The cracks produced in this slab (Figure 9) had originated on the tension side at the edge of the circular loading plunger and propagated diagonally towards each corner. This shows that the slab suffered a shear mode of failure. Compared to the SRC 8 control specimen, the strength demonstrated by BRC12 specimen was $68 \%$ and the ultimate load was $26.40 \mathrm{kN}$ at central deflection of $10.16 \mathrm{~mm}$.
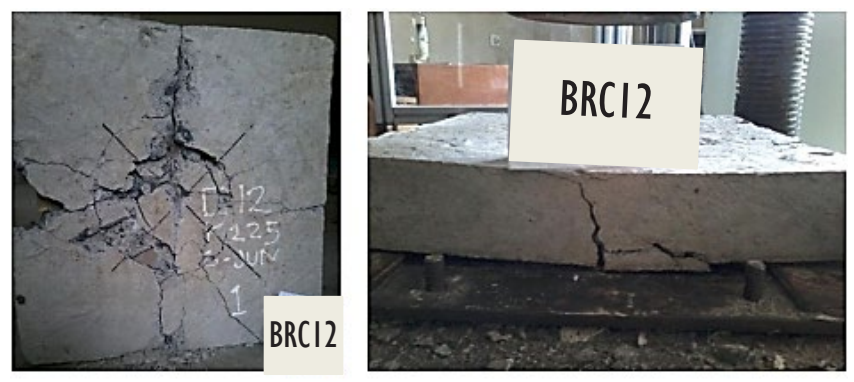

FIGURE 9. Crack pattern in BRC12 slab

\section{DUCTILITY INDEX AND STIFFNESS}

Ductility refers to the capability of a material, structure, or section to withstand inelastic deformation before the collapse without considerable loss in strength or resistance. This structural characteristic is quite important since it permits redistribution of stress and increases deflections to point towards failure. The ability of a reinforced structure to deform at the plastic stage is important for various reinforced concrete design strategies. To analyze the influence of substituting steel with bamboo for reinforcement on ductility of the specimens, the ductility index was determined at failure load as $I_{f}=\delta \delta_{y}$ and the central yield deflection $\left(\delta_{y}\right)$ was taken as the standard for the obtained result.
Stiffness refers to the capability of structures to resist load/displacement. It is also an important property of RC structures because it determines the serviceability of $\mathrm{RC}$ structures like crack characteristics and displacement. Owing to the disreputable unpredictability of the slab deflection, stiffness of RC slabs is of crucial importance (Reid 1985). During this investigation, stiffness was calculated as the ratio of the ultimate load to the yield deflection. The stiffness of the evaluated specimens as well as their ductility index are indicated in Table 4. Moreover, the ratio of the values for the bamboo reinforced slabs and the values of the control slabs are also presented. 
TABLE 4. Ductility index and stiffness

\begin{tabular}{lcccc}
\hline \multicolumn{1}{c}{ Specimen } & $I_{f}=\delta / \delta_{y}$ & Ratio & $K=P_{u} / \delta_{y}(\mathrm{~N} / \mathrm{mm})$ & Ratio \\
\hline SRC8 & 1.41 & 1.00 & 5250.34 & 1.00 \\
BCR8 & 1.32 & 0.93 & 3773.81 & 0.72 \\
BCR10 & 1.12 & 0.80 & 3742.48 & 0.71 \\
BCR12 & 1.09 & 0.78 & 2599.19 & 0.50 \\
\hline
\end{tabular}

It was observed that the ductility index at failure load of the BRC slabs were equivalent to that of the control slab up to $93 \%$. Moreover, the stiffness values demonstrated by the BRC specimens were $50-72 \%$ in comparison to the control specimen. The serviceability of the concrete structures is determined by deflections and concrete crack control and these two are in turn influenced by stiffness of the reinforcement substance used. If the concrete gets cracked, the crack width and accordingly the deflection and curvature are determined by stiffness of the substance used for reinforcement which bridges the crack. Utilization of bamboo for crack control can prove to be ineffective as the modular ratio demonstrated by bamboo is over 10. Also, the young modulus of bamboo is characteristically smaller than the young modulus of the concrete (Zuhri et al. 2017). However, by shortening the spacing of bamboo or other softer material used for reinforcement, structures comparable to SRC members can be developed.

\section{ENERGY ABSORPTION CAPACITY}

An extremely important property for the analysis of the fracture work of the overall structure is the energy absorption. The value of energy absorption was determined by calculating the area under the loaddeflection curve. Energy absorption levels of all tested specimens are shown in Figure 10. Bamboo reinforced concrete slabs demonstrated comparable energy absorption level to that of the control slab. Still, utilization of bamboo as reinforcement material caused marginally reduction in energy absorption of the specimens. For BRC8, BRC10 and BRC12, the energy absorption was decreased by $17.44,30.96$ and $34.16 \%$, respectively. Several different factors determine the energy absorption capacity such as geometry of the specimen, type of material and matrix and the conditions used for loading and processing (Zuhri et al. 2017). Reduction in the energy absorption noticed in the case of bamboo reinforced slabs is because of the increased flexibility coefficient and modular ratio of bamboo and low young modulus of the bamboo in comparison to the concrete together with the considerable reduction in stiffness.

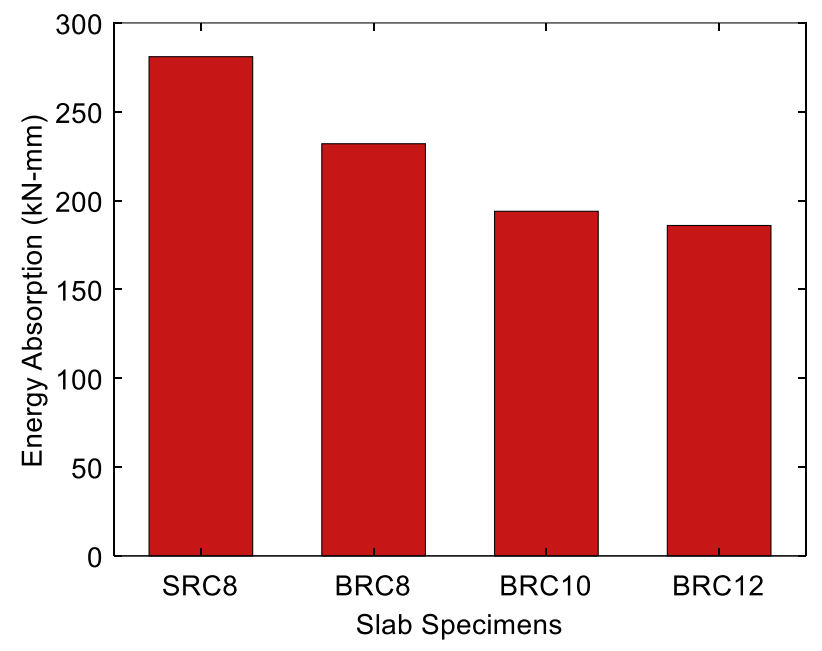

FIGURE 10. Energy absorption 


\section{CONCLUSION}

In this study, the structural behaviour of BRC slabs under concentrated load was examined. The role of bamboo strips from $G$. apus as reinforcement material in concrete slabs has been analyzed by experiments. Based on the results, certain conclusions can be drawn as follows: On exposure to concentrated load, the BRC slabs perform just like the SRC slabs. Compared to SRC slabs, strength of $82 \%$ can be acquired by the BRC slabs. Ductility demonstrated by the two types of specimens investigated in this research was almost equivalent i.e. up to $93 \%$. Stiffness demonstrated by the BRC slabs was equivalent i.e. up to $72 \%$ in comparison to that of SRC slabs. The reduction in energy absorption noticed in the case of BRC specimens is because of the increased flexibility coefficient and the modular ratio of bamboo and low young modulus of the bamboo in comparison to the concrete together with the considerable reduction in stiffness. The structural behaviour of BRC slabs is quite comparable to that of the SRC slabs. Bamboo can be a promising substitute for steel when it comes to concrete reinforcement. However, further research must still be carried out.

\section{ACKNOWLEDGEMENTS}

The authors are grateful to the Jenderal Soedirman University, Indonesia for funding this research. Assistance provided by Erwin Sandi for performing different tests is also acknowledged.

\section{REFERENCES}

Agarwal, A., Nanda, B. \& Maity, D. 2014. Experimental investigation on chemically treated bamboo reinforced concrete beams and columns. Computers \& Chemical Enginering 71: 610-617.

Anandamurthy, A., Guna, V., Ilangovan, M. \& Reddy, N. 2017. A review of fibrous reinforcements of concrete. Journal of Reinforced Plastics and Composites 36(7): 519-552.

Angulo-Ibáñez, Q. 2017. Performance analysis of wooden reinforcement in rammed earth walls. Periodica Polytechnica Civil Engineering 61(4): 882-888.

Archila, H., Harries, K.A., Kaminski, S., Trujillo, D. \& Escamilla, E.Z. 2018. Bamboo reinforced concrete: A critical review. Materials and Structures 51(102): 1-18.

Audu, M.T. \& Raheem, A.A. 2017. Flexural behaviour of fanpalm reinforced concrete slabs. Journal of Building Engineering 13: 63-67.

BSN SNI 1974:2011. 2011. Concrete Compressive Strength Test Methods with Cylindrical Specimens. Indonesia: Badan Standardisasi Nasional (BSN).

BSN SNI 15-2049-2004. 2004. Portland Cement. Indonesia: Badan Standardisasi Nasional (BSN).

BSN SNI 03-1968-1990. 1990. Testing Method on Sieve Analysis of Fine and Coarse Aggregate. Indonesia: Badan Standardisasi Nasional (BSN).
Bhonde, D., Nagarnaik, P.B., Parbat, D.K. \& Waghe, U.P. 2014. Experimental investigation of bamboo reinforced concrete slab. American Journal of Engineering Research 3(1): 128-131.

Chithambaram, S.J. \& Kumar, S. 2017. Flexural behaviour of bamboo based ferrocement slab panels with flyash. Construction and Building Materials 134: 641-648.

Dewi, S.M \& Nuralinah, D. 2017. The recent research on bamboo reinforced concrete. In MATEC Web of Conferences 103: 02001

Dey, A. \& Chetia, N. 2018. Experimental study of bamboo reinforced concrete beams having various frictional properties. Materials Today: Proceeding 5(1): 436-444.

Fergusson-Calwell, T.C. 2015. Viability of bamboo reinforced concrete for residential housing in Indonesia. Bachelor Thesis: Charles Darwin University (Unpublished).

Ghavami, K. 2005. Bamboo as reinforcement in structural concrete elements. Cement and Concrete Composites 27(6): 637-349.

Ghavami, K. 1995. Ultimate load behaviour of bambooreinforced lightweight concrete beams. Cement and Concrete Composites 17(4): 281-288.

Haryanto, Y., Hu, H.T., Han, A.L., Wariyatno N.G., Sudibyo, G.H., Hidayat, B.A. \& Naqiyah, K. 2019a. Precast segmental bamboo reinforced concrete beams with bolted connections subjected to flexural loads: An experimental investigation. In IOP Conference Series: Material Science and Engineering. p. 615.

Haryanto, Y., Hu, H.T., Han, A.Y., Atmajayanti, A.T., Galuh, D.L.C. \& Hidayat, B.A. 2019b. Finite element analysis of T-section RC beams strengthened by wire rope in the negative moment region with an addition of steel rebar at the compression block. Jurnal Teknologi 81(4): 143-154.

Haryanto, Y., Gan, B.S., Widyaningrum, A., Wariyatno, N.G. \& Fadli, A. 2018. On the performance of steel wire rope as the external strengthening of RC beams with different endanchor type. Jurnal Teknologi 80(5): 145-154.

Haryanto, Y., Gan, B.S. \& Maryoto, A. 2017. Wire rope flexural bonded strengthening system on RC-beams: A finite element simulation. International Journal of Technology 8(1): 134-144.

Haryanto, Y., Gan, B.S., Widyaningrum, A. \& Maryoto, A. 2017. Near surface mounted bamboo reinforcement for flexural strengthening of reinforced concrete beams. Jurnal Teknologi 79(6): 233-240.

Haryanto, Y., Satyarno, I. \& Sulistyo, D. 2012. Strength and ductility of reinforced concrete T-beams strengthened in the negative moment region with wire rope and mortar composite. Civil Engineering Forum 21(1): 1163-1169.

Hidayat, B.A., Hu, H.T., Han, A.L., Haryanto, Y., Widianingrum, A. \& Pamudji, G. 2019. Nonlinear finite element analysis of traditional flexural strengthening using betung bamboo (Dendrocalamus asper) on concrete beams. In IOP Conference Series: Material Science and Engineering. p. 615.

Ismail, R., Bon, Y.C., Adiba, N., Joolkeepri \& Ishak, I.S. 2018. Strength behaviour of bamboo-reinforced concrete slabs. In IOP Conference Series: Materials Science and Engineering. p. 431. 
Kankam, C.K. \& Odum-Ewuakye, B. 2006. Babadua reinforced concrete two-way slabs subjected to concentrated loading. Construction and Building Materials 20(5): 279-285.

Kankam, C.K. \& Odum-Ewuakye, B. 2001. Flexural behaviour of babadua reinforced one-way slabs subjected to thirdpoint loading. Construction and Building Materials 15(1): 27-33.

Karthik, S., Rao, P.R.M. \& Awoyera, P.O. 2017. Strength properties of bamboo and steel reinforced concrete containing manufactured sand and mineral admixtures. Journal of King Saud University - Engineering Sciences 29(4): 400-406.

Mali, P.R. \& Datta, D. 2018. Experimental evaluation of bamboo reinforced concrete slab panels. Construction and Building Materials 188: 1092-1100.

Maruthupandian, G., Saravanan, R., Kumar, S.S. \& Sivakumar, B.G. 2016. A study on bamboo reinforced concrete slabs. Journal of Chemical and Pharmaceutical Science 9(2): 978-980.

Moroz, J.G., Lissel, S.L. \& Hagel, M.D. 2014. Performance of bamboo reinforced concrete masonry shear walls. Construction and Building Materials 61: 125-137.

Nahar, T.T. \& Rahman, M.M. 2015. Strengthening of RCC beams using bamboo sticks. International Journal of Advanced Science and Technology 79: 15-24.

Puri, V., Chakrabortty, P., Anand, S. \& Majumdar, S. 2017. Bamboo reinforced prefabricated wall panels for low cost housing. Journal of Building Engineering 9: 52-59.

Rahman, M.M., Rashid, M.H., Hossain, M.A., Hasan, M.T. \& Hasan, M.K. 2011. Performance evaluation of bamboo reinforced concrete beam. International Journal of Engineering \& Technology 11(4): 142-146.

Reid, S.G. 1985. The flexural rigidity of reinforced concrete slabs. Computers \& Structures 20(6): 929-938.

Sen, T. \& Reddy, H.N.J. 2011. A numerical study of strengthening of RCC beam using natural bamboo fibre. International Journal of Computer Theory and Engineering 3(5): 707-713

Sharma, B., Gatóo, A. \& Ramage, M.H. 2015a. Effect of processing methods on the mechanical properties of engineered bamboo. Construction and Building Materials 83: 95-101.

Sharma, B., Gatóo, A., Bock, M., Mulligan, \& Ramage, M.H. 2015b. Engineered bamboo: State of the art. Proceeding of the Institution of Civil Engineers - Construction Materials 168(2): 57-67.

Terai, M. \& Minami, K. 2011. Fracture behaviour and mechanical properties of bamboo reinforced concrete members. Procedia Engineering 10: 2967-2972.

Wariyatno, N.G., Haryanto, Y. \& Sudibyo, G.H. 2017. Flexural behaviour of precast hollow core slab using PVC pipe and styrofoam with different reinforcement. Procedia Engineering 171: 909-916.

Wibowo, A., Wijatmiko, I. \& Nainggolan, C.R. 2017. Structural behaviour of lightweight bamboo reinforced concrete slab with EPS infill panel. In AIP Conference Proceedings. $\mathrm{p}$ 1887.

Xiao, Y., Yang, R.Z. \& Shan, B. 2013. Production, environmental impact and mechanical properties of glubam. Construction and Build Materials 44: 765-773.

Xu, Q., Chen, X., Chen, J.F., Harries, K.A., Chen, L. \& Wang, Z. 2019. Seismic strengthening of masonry walls using bamboo components. Advances in Structural Engineering 22(14): 1-16

Zhu, M., Long, Y., Jiang, Q. \& Li, J. 2015. Experimental study on bending bearing capacity of bamboo-reinforced concrete plate. In Proceeding of 2015 International Forum on Energy, Environment Science and Materials. pp. 526-531.

Zuhri, M.Y.M., Liao, Y., Wang, Q.Y. \& Guan, Z.W. 2017. The energy absorbing properties of bamboo-based structures. Journal of Sandwich Structures and Materials 21(3): 10321054.

Yanuar Haryanto, Hsuan-Teh Hu* \& Banu Ardi Hidayat Department of Civil Engineering

College of Engineering

National Cheng Kung University

No. 1 University Road

Tainan, 701

Taiwan

Nanang Gunawan Wariyatno, Ay Lie Han \& Banu Ardi Hidayat Department of Civil Engineering

Faculty of Engineering

Diponegoro University

Jln. Prof. Soedarto, Tembalang

Semarang, 50275

Indonesia

Yanuar Haryanto \& Nanang Gunawan Wariyatno

Department of Civil Engineering

Faculty of Engineering

Jenderal Soedirman University

Jln. Mayjen. Sungkono KM 5, Blater

Purbalingga, 53371

Indonesia

Hsuan-Teh $\mathrm{Hu}^{*}$

Department of Civil and Disaster Prevention Engineering

College of Engineering and Science

National United University

No. 2, Lien Da, Nan Shih Li

Miaoli, 36063

Taiwan

*Corresponding author; email: hthu@ncku.edu.tw

Received: 7 March 2020

Accepted: 1 July 2020 